\title{
Over basisvakken en boventonen
}

Citation for published version (APA):

Rommers, G. M. (2016). Over basisvakken en boventonen: de wondere wereld van revalidatiegeneeskundig onderwijs. Maastricht University. https://doi.org/10.26481/spe.20161202cr

Document status and date:

Published: 02/12/2016

DOI:

$10.26481 /$ spe.20161202cr

Document Version:

Publisher's PDF, also known as Version of record

\section{Please check the document version of this publication:}

- A submitted manuscript is the version of the article upon submission and before peer-review. There can be important differences between the submitted version and the official published version of record.

People interested in the research are advised to contact the author for the final version of the publication, or visit the DOI to the publisher's website.

- The final author version and the galley proof are versions of the publication after peer review.

- The final published version features the final layout of the paper including the volume, issue and page numbers.

Link to publication

\footnotetext{
General rights rights.

- You may freely distribute the URL identifying the publication in the public portal. please follow below link for the End User Agreement:

www.umlib.nl/taverne-license

Take down policy

If you believe that this document breaches copyright please contact us at:

repository@maastrichtuniversity.nl

providing details and we will investigate your claim.
}

Copyright and moral rights for the publications made accessible in the public portal are retained by the authors and/or other copyright owners and it is a condition of accessing publications that users recognise and abide by the legal requirements associated with these

- Users may download and print one copy of any publication from the public portal for the purpose of private study or research.

- You may not further distribute the material or use it for any profit-making activity or commercial gain

If the publication is distributed under the terms of Article $25 \mathrm{fa}$ of the Dutch Copyright Act, indicated by the "Taverne" license above, 


\section{Maastricht University}

\section{Prof.dr. G.M.(Clemens) Rommers}

Faculty of Health, Medicine and Life Sciences

\section{Over basisvakken en boventonen}

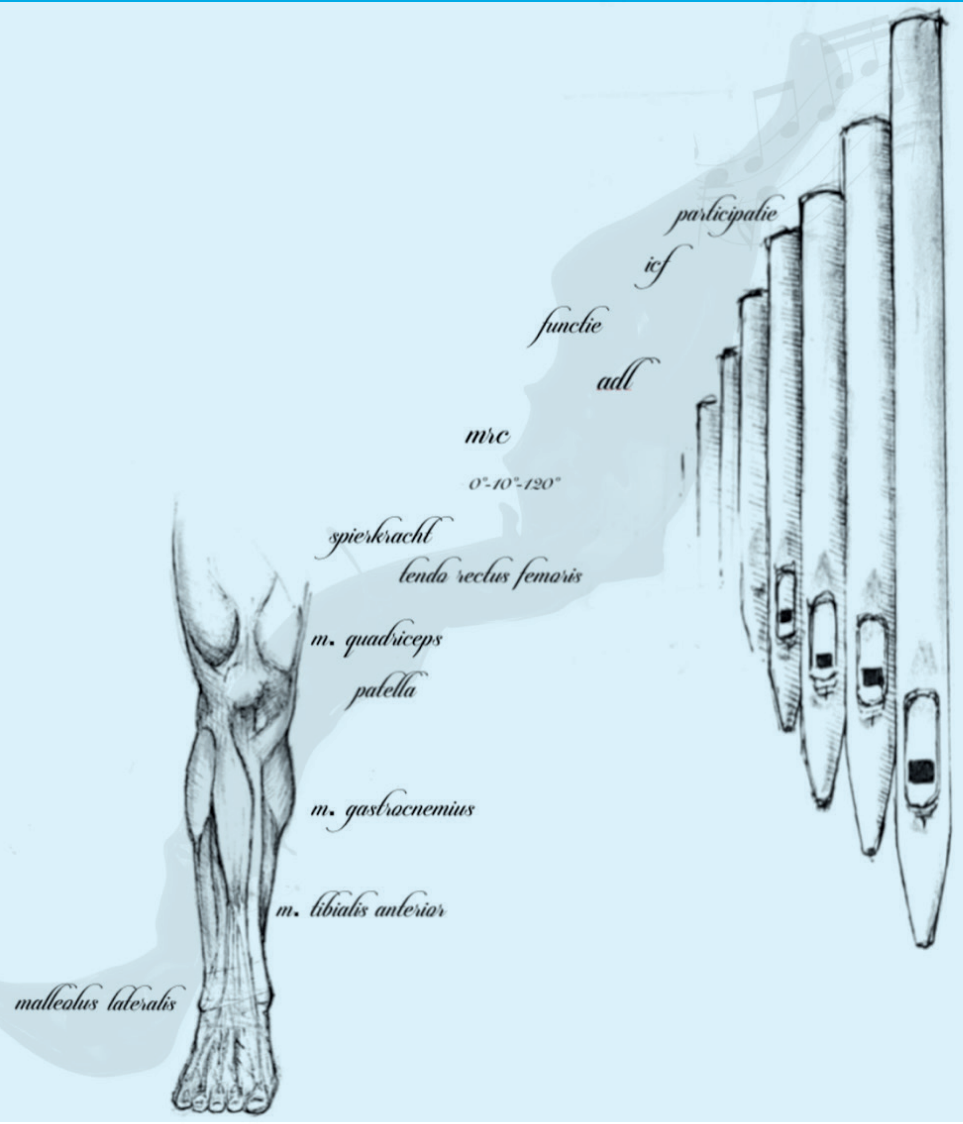




\section{Over basisvakken en boventonen}


ISBN: $978-90-5681-469-4$

NUR: 876

Cover design: Emmy HWM Rommers

All rights reserved. No part of this publication may be reproduced, modified, stored in a retrieval system or made public without the prior written permission of the author or publisher. 


\title{
Over basisvakken en boventonen
}

\author{
de wondere wereld van \\ revalidatiegeneeskundig onderwijs
}

\begin{abstract}
Inaugurele rede
Uitgesproken bij openbare aanvaarding van het ambt van bijzonder hoogleraar Revalidatiegeneeskunde in het bijzonder onderwijs aan de Faculty of Health Medicine and Life Sciences van de Universiteit Maastricht.
\end{abstract}

Maastricht, 2 december 2016

Door Prof. dr. G.M. Rommers 
Geachte Mevrouw de Rector Magnificus,

Gewaardeerde toehoorders,

Vandaag een bijzondere dag voor $U$ en voor mij. Graag heet ik $U$ van harte welkom vanmiddag bij deze oratie. Dat ik hier nu sta met zoveel collega's, familie en vrienden om me heen geeft me een blij en positief gevoel. $U$ vraagt zich wellicht af: revalidatiegeneeskunde en onderwijs, hoezo?

Vanmiddag neem ik $U$ mee op een reis door de wondere wereld van revalidatiegeneeskunde en onderwijs. Voor mij begon deze reis ruim 25 jaar geleden: destijds AGNIO revalidatiegeneeskunde in Beetsterzwaag, Friesland, mijn eerste echte revalidatiebaan. Vol verwondering zag ik wat er allemaal in de kliniek van een revalidatiecentrum gebeurde. Enkele maanden later kwam er een verzoek van Johan Groothoff, mijn latere zeer gewaardeerde copromotor, van de afdeling sociale geneeskunde van de Rijksuniversiteit Groningen, of hij met een groep studenten langs kon komen om wat meer van een revalidatiecentrum te laten zien. En of er iemand was die de studenten uit kon leggen wat revalidatiegeneeskunde is en wat een revalidatiearts doet. Neemt u van mij aan, deze vragen worden vandaag nog steeds gesteld door studenten in Groningen, Maastricht en bij de andere medische faculteiten in Nederland.

Mij intrigeert deze vraag bovenmate: Welk beeld roept ons vak op bij de studenten en wat horen en zien ze er van in het medisch curriculum? Maar ook: Wat vindt de revalidatiegeneeskunde dat studenten over ons vak moeten weten? Kennelijk moeten we met elkaar nog veel huiswerk doen om dit beeld helder te maken. Graag help ik $U$ vanmiddag op weg. 


\section{Introductie}

De revalidatiegeneeskunde is als relatief jong vakgebied de laatste 20 jaar enorm gegroeid. In academische zin zijn er leerstoelen revalidatiegeneeskunde aan alle geneeskunde faculteiten en aan de technische universiteit Twente in Enschede. Alle ziekenhuizen en revalidatiecentra zijn in meer of mindere mate voorzien van revalidatiegeneeskundige expertise en ook de Zelfstandige Behandel Centra (ZBC) geven onderdak aan steeds meer revalidatieartsen. Het aantal Assistenten In Opleiding tot Specialist (AIOS) is fors gestegen. Ondanks alle politieke wensen zijn er nog nooit zoveel AIOS in opleiding geweest als op dit moment.

We zouden kunnen denken: prima gedaan, de revalidatiegeneeskunde is alom bekend.

Maar dan neem ik $U$ graag mee naar de basisopleiding geneeskunde: de eerste vraag die ons daar gesteld wordt: wat doen jullie als revalidatiearts? En welke patiënten zien jullie?

Onbekend in het curriculum?

Een inventariserend onderzoek naar revalidatiegeneeskundig onderwijs aan de Nederlandse medische faculteiten, uitgevoerd door Groningse studenten in het kader van een bachelor keuzeblok, liet evenwel zien dat alle medische faculteiten wel degelijk aandacht geven aan de revalidatiegeneeskunde. In de bachelor- en masterfase wordt in meer of mindere mate onderwijs, coschappen en wetenschappelijk onderzoek aangeboden. Wellicht wordt dit niet allemaal als revalidatiegeneeskunde gezien door de studenten. Een college CVA en gevolgen wordt in een aantal gevallen samen met de neurologie gedaan. Ook multitrauma, pijnbehandeling en dwarslaesie: allemaal onderwerpen die niet alleen bij de revalidatiegeneeskunde voorkomen.

Waar missen we dan de boot?

\section{Revalidatiegeneeskunde}

Het vakgebied is ontstaan uit de fysiotherapie en fysicotherapie. In het lezenswaardige boek Specialisme in Beweging van collega van der Meij ${ }^{1}$ wordt een boekje open gedaan over de pioniers in de revalidatiegeneeskunde. Vorig jaar hebben we als specialisme ons 60 -jarig bestaan gevierd. Van een kleine groep dokters in het 
bewegingsapparaat, weggestopt in de gymzaal of in de kelder van het ziekenhuis, groeiden we uit tot een specialisme dat de geneeskundige gemeenschap duidelijk wat te bieden heeft.

Dit brengt mij bij de titel van deze oratie: Over basisvakken en boventonen.

Laten we beginnen met de basisvakken.

Dit jaar 40 jaar geleden werd door Koningin Juliana in Maastricht de stichtingsacte ondertekend waarbij de Rijksuniversiteit Limburg en later Maastricht University haar gezicht kreeg. De geneeskundeopleiding in Maastricht heeft sinds haar oprichting in 1976 een andere route voor de basisvakken gekozen. Probleemgestuurd onderwijs (PBL) werd het nieuwe woord. We bevinden ons in een bevoorrechte positie dat onze revalidatiearts collega Wilbert Bakx de trotse bezitter is van collegekaart nummer $1 . \mathrm{Hij}$ was destijds de eerste van het alfabet die in Maastricht werd ingeschreven als student geneeskunde. Waarlijk de revalidatiegeneeskunde aan de basis van de medische faculteit van Maastricht. Wip, we schrijven geschiedenis!

Probleemgestuurd onderwijs betekent voor de student dat deze zelf op zoek gaat naar de informatie over het medisch of fysiologisch probleem dat wordt aangeboden. Daarbij wordt gezocht binnen de basisvakken: anatomie, fysiologie en pathologie om het onderliggende medisch probleem te kunnen duiden. Binnen de tutorgroep bestuderen de studenten allemaal een deel van de stof en delen de bevindingen met de groepsgenoten. Op die manier wordt de stof verwerkt en vanuit het probleemgebied aangepakt. De rol van de tutor is meer begeleidend en stimulerend dan docerend. Mijn ervaring is dat de klinische context van de problemen aan het eind van de bachelor fase nog weinig landt en van de nodige uitleg moet worden voorzien.

Het bewegingsapparaat, waar de revalidatiegeneeskunde zijn basis in vindt, is voor de meeste studenten, zeker met de uitgebreide anatomie, een lastige hobbel. Maar wat maakt het bewegingsapparaat als onderwijsonderdeel nu zo leuk en zo bijzonder?

Allereerst: je kunt er aan de buitenkant al heel veel van zien. Huid, spiercontouren en gewrichtsbewegingen zijn eenvoudig te observeren en hands-on te onderzoeken; daar is geen laboratorium of scanneronderzoek voor nodig. Je 
hebt direct lijfelijk contact met de patiënt en in veel gevallen leidt de anamnese en het lichamelijk onderzoek naar de diagnose. Je kunt de bewegingen in gewrichten uitvoeren en gewrichten letterlijk voelen. Volgens mij voor het ziekenhuis een goedkoop en deskundig diagnosticum. Maar juist dat lichamelijk onderzoek van het bewegingsapparaat komt in de geneeskunde opleiding maar beperkt aan de orde. Het vaardigheidsonderwijs in het skills lab heeft geleid tot het bijna beroemde hoofdstuk 9 bewegingsapparaat in het boek Fysische diagnostiek ${ }^{2}$ waarbij ik samen met de zeer gewaardeerde collega's Corry van der Sluis en Rienk Dekker, revalidatieartsen uit het UMCG, vorm heb mogen geven aan een systematisch onderzoek van het bewegingsapparaat. We hopen dat de inhoud hiervan samen met de in Maastricht gebruikte Vaardigheden In Geneeskunde (VIG) boekjes de studenten verder helpt om de basis van het bewegingsapparaat te doorgronden. Voor de docenten van het vaardigheidsonderwijs en de tutoren van de onderwijspoli een leidraad: houd je bij de instructie van het onderzoek van het bewegingsapparaat aan de gedoceerde methode om verwarring bij de studenten te voorkomen. Te vaak wordt men verleid om de eigen "handige" manier aan de studenten voor te doen en te melden dat ze het VIG boekje etc. maar moeten vergeten. Het zou jammer zijn als de Maastrichtse student met onvoldoende vaardigheden deze universiteit verlaat.

Het klinisch redeneren bij de problemen van het houding- en bewegingsapparaat wordt in het skills lab met voorbeeld patiënten onderwezen. Het ligt in de bedoeling om vanuit deze leerstoel samen met de collega's van het skills lab dit klinisch redeneren verder uit te bouwen en van nieuwe impulsen te voorzien. We weten immers dat de huisarts nu reeds ca $30 \%$ van de patiënten in de praktijk ontvangt met klachten van het houding- en bewegingsapparaat. Hebt $U$ allemaal al niet zelf in meer of mindere mate kennis gemaakt met de verstuikte enkel, de wisselende lage rugpijn of de onwillige schouder? Vandaar dat we vanuit de revalidatiegeneeskunde een bijdrage willen leveren aan het Maastrichtse curriculum. 
Is het bewegingsapparaat al wat de klok slaat? Natuurlijk niet!

Het zenuwstelsel vanuit de neurologie met als belangrijke pijler het cognitief functioneren van de mens vormt binnen de revalidatiegeneeskunde een groot aandachtsgebied. Binnen de Caphri onderzoeksgroep in Maastricht mogen we de chronische pijn van het bewegingsapparaat zeker niet onvermeld laten. Mijn beide collega's Jeanine Verbunt en Rob Smeets stelden zich voor om bij mijn komst hier in Maastricht een echte pijndokter van mij te gaan maken. Hun bevlogenheid rondom dit vakgebied waardeer ik zeer en ik zie zeker de meerwaarde van de pijn benadering maar tot een overstap is het nog niet gekomen.

Hersenfunctie, en met name het lerend brein bij niet aangeboren hersenletsel (NAH), heeft met de collega's Wip Bakx, Martine Moennekens, Veronique Moulaert en Geerie Winnubst zeer deskundige pleitbezorgers. Het overdragen aan studenten van kennis over het functioneren van het beschadigde brein vergt meer van de basisvakken dan alleen het vergelijken met het gezonde brein.

Met de volgende twee voorbeelden laat ik $U$ dit zien. Het probleem hemianopsie (slechts een deel van het gezichtsveld kunnen gebruiken) na een CVA valt de student met het neurologieboek in de hand nog wel uit te leggen. Het veel complexere begrip neglect (waarbij de waarneming wel wordt gedaan maar dit niet leidt tot een adequate handeling) is aan de hand van de basisvakken minder goed te begrijpen. Hierdoor blijft dit klinische verschijnsel vaak onderbelicht in het ziekenhuis en wordt pas duidelijk tijdens de revalidatiebehandeling. Helaas blijkt het dan ook nog moeilijk te behandelen.

Het tweede voorbeeld betreft het aan het ziekenhuisbed beoordelen van cognitief functioneren met bedside testen zoals de Montreal Cognitive Assessment (MoCA) ${ }^{3}$. Deze test geeft enig inzicht in het ontwikkelen van cognitieve functiestoornissen. Met name het beoordelen van de leerbaarheid en trainbaarheid van het beschadigde brein is hierdoor mogelijk. Door dit aan de studenten te leren hopen we dat in de toekomst de informatie vanuit de klinische afdelingen kan verbeteren. Nu horen we regelmatig dat het beter gaat met de patiënt en we zeker klinische revalidatie moeten overwegen. Helaas stoelt dit optimisme vaak op observatie zonder het opnieuw uitvoeren van de genoemde 
MoCA test. In onze onderwijsbijdragen in het curriculum zullen we dus naast het bewegingsapparaat met name de cognitieve screening meer inhoud moeten geven. We weten allemaal wat er op ons af komt nu groter wordende groepen ouderen met cognitieve functiestoornissen onze spreekuren zullen gaan bezoeken. De arts van morgen zullen we hiervoor beter moeten toerusten. Vandaar dat we samen met de neurologie in het coschap beschouwend de masterfase student willen stimuleren om de cognitieve functies gestandaardiseerd in kaart te gaan brengen. Binnen het Arts Klinisch Onderzoeker (AKO) onderwijs in Maastricht geven we hier vorm aan middels klinische colleges om het beschadigde brein beter toegankelijk te maken voor de studenten. Het is een begin en er is nog veel werk aan de winkel.

\section{Revalidatiegeneeskunde en (medisch) onderwijs}

Zoals reeds eerder vermeld is het onderwijs in de revalidatiegeneeskunde aan de medische faculteiten voor de student niet altijd goed zichtbaar. De vraag "wat doet de revalidatiearts", wordt ons nog steeds vaak gesteld. Hoe komt dit? Als we in de literatuur kijken naar het onderwijs in de revalidatiegeneeskunde dan is hier heel weinig over gepubliceerd. In een PubMed search Rehabilitation Medicine and Clerkship Learning zijn hierover in de afgelopen 20 jaar slechts enkele hits te vinden ${ }^{4,5}$.

Figuur 1: Het ICF model

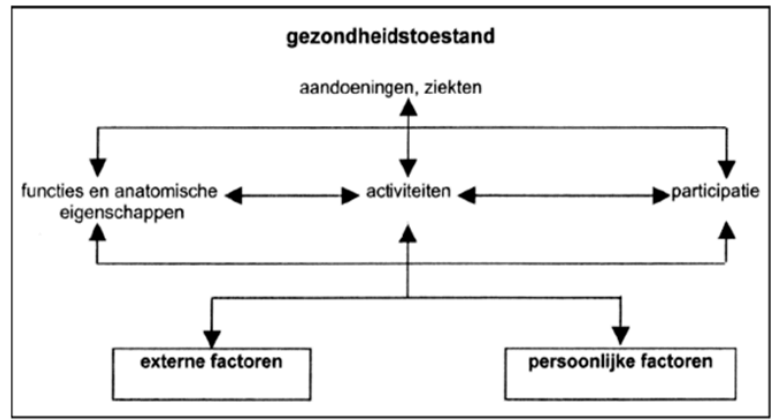

ICF: International Classification of Functioning, Disability and Health

Fig 1: Het ICF model 
Het doceren in de revalidatiegeneeskunde vergt van de docent en de student een andere mindset dan in de basisvakken.

Via het concept van de International Classification of Function, Disabilitiy and Health (ICF) ${ }^{6}$ worden studenten uitgedaagd om naast de recent verworven medische basiskennis na te denken over het concept van functioneren en participatie.

Een voorbeeld van de onderwijspoli in Maastricht en Hoensbroek: Een kleine groep studenten van de tutorgroep bezoekt een poliklinische of klinische afdeling om middels een begeleid patiëntencontact kennis en vaardigheden op te doen en dit in een korte presentatie door te geven aan de groepsgenoten. Het concept van functioneren van mensen na opname in een ziekenhuis levert veel vragen op. Met name het uitvragen van de activiteiten van het dagelijks leven (ADL) wordt in eerste instantie als vreemd ervaren. Waarom zou je vragen naar toiletbezoek en het zelf kunnen wassen en kleden? Uit ervaring weten we dat mensen die opgenomen worden in het ziekenhuis juist deze basisvaardigheden het eerst weer zelf willen kunnen uitvoeren. Dit onderdeel komt in de standaard ziekteanamnese niet naar voren en zelfs vanuit de verpleegkundige staf van de afdeling kunnen ADL vragen niet altijd worden beantwoord. Deze soms zeer gedetailleerde benadering van het functioneren kost veel tijd tijdens de anamnese. Door tijdgebrek en veel patiëntencontacten per uur worden de noodzakelijke vragen over menselijk functioneren niet gesteld of er wordt aangenomen dat daar geen problemen mee zijn. Vandaar dat we tijdens de onderwijspoli en de keuzecoschappen revalidatiegeneeskunde hier veel aandacht aan besteden. De vraag rijst dan of dit niet een basisvaardigheid moet zijn voor elke arts die in contact komt met klinische en/of poliklinische patiënten. Het bewust worden van menselijk functioneren na bv. trauma, CVA, operatie of chemotherapiebehandeling lijkt een open deur maar dient onzes inziens in de basisvakken te worden geïntegreerd om later problemen in het functioneren te voorkomen. Juist in een vroeg moment tijdens de ziekenhuisopname dienen potentiële functieproblemen te worden geïdentificeerd. Het gebeurt helaas nog te vaak dat vlak voor het ontslag ADL beperkingen de overgang naar de thuissituatie in de weg staan. Dit terwijl ruim van tevoren de $A D L$ en thuissituatie al bekend had kunnen zijn. 
Vandaar dat we vanuit deze leerstoel het samenwerken in het ziekenhuis middels nieuwe onderwijsvormen rondom functioneren willen stimuleren.

\section{Samenwerken}

Vanuit de sociale geneeskunde is een opzet gemaakt voor betere samenwerking door het houden van een sociaal wijkteamoverleg. Hierbij leggen de coassistenten in het laatste jaar van de masterfase een (verpleeg)huisbezoek af. Ze werken dit uit om beperkingen in functioneren in kaart te brengen en deze daarna in de multidisciplinaire groep met studenten van paramedische en verpleegdisciplines te bespreken ${ }^{7}$.

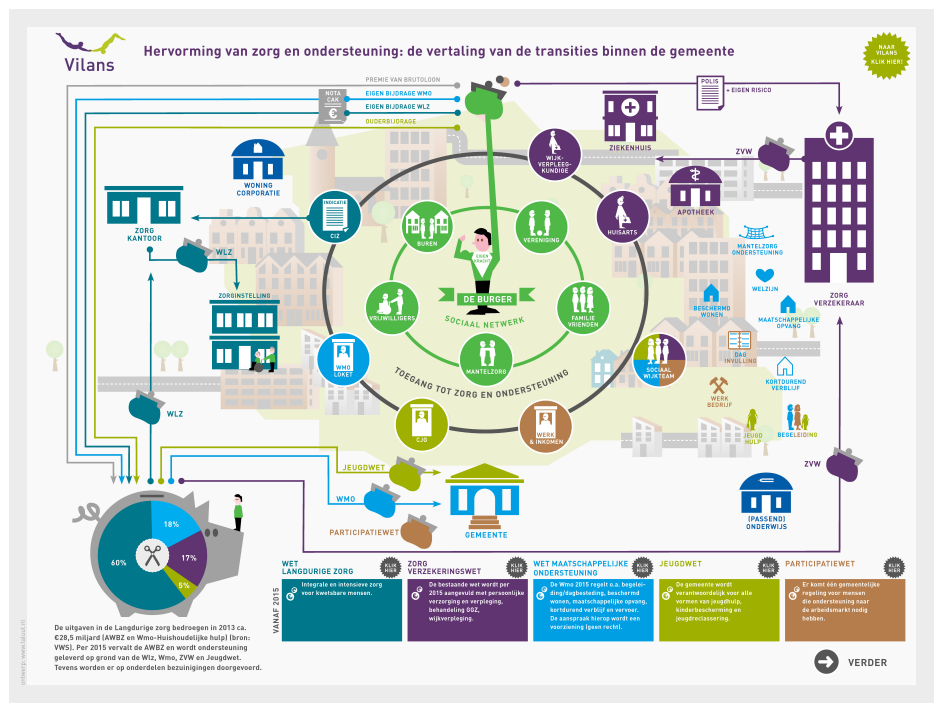

Fig 2: de transities binnen de gemeente

Deze vorm van onderwijs waarbij geneeskundige en paramedische disciplines samen worden gebracht is uniek in Nederland. Op deze manier worden de studenten gestimuleerd om samen te werken aan oplossingen welke de grenzen van hun eigen vakgebied overstijgen.

Samen met collega Willibrord Beemsterboer, sociaal geneeskundige, zijn we druk bezig om de studenten inzicht 
te geven in de sociale regelgeving in de eerste lijn en het functioneren in de thuissituatie.

Revalidatiegeneeskunde heeft wat extra's te bieden voor een breed scala aan klinische en sociaal geneeskundige vakken. Vandaar dat de Adelante organisatie in samenwerking met Zuyd Hogeschool start met het interdisciplinair werken van paramedische studenten tijdens de stage in het revalidatiecentrum en ziekenhuis. Dit proces waarvan de coördinatie bij het Kenniscentrum van Adelante Hoensbroek ligt geeft een prima aanzet voor de toekomst. Coassistenten geneeskunde gaan tijdens het keuzecoschap samen met de paramedische studenten onder supervisie van de revalidatiearts interdisciplinair aan het werk om het functioneren van patiënten te verbeteren. Of de inzet van studenten ook tot de beoogde vermindering van werkbelasting voor de senior therapeuten leidt is op dit moment nog niet te voorspellen. Dat we nog beter moeten samenwerken voor de gezondheidszorg van morgen lijkt duidelijk. Zeker in het toenemend complexe zorglandschap waar korte klinische opnames en meer specialistische zorg buiten het ziekenhuis de communicatie tussen patiënt en zorgverleners nog belangrijker maakt, kan de revalidatiegeneeskunde hiervoor tools aanleveren in de basisvakken.

Terugkomend op de titel van deze oratie basisvakken en boventonen wordt het hoog tijd voor de boventonen.

Zoals u kunt zien komt nu het instrument in beeld waar heel veel boventonen mee te maken zijn. Het orgel. Metafoor voor een instrument met bijna oneindige mogelijkheden en een rijke klankkleur. Bij mij roept het nog steeds geweldige herinneringen op aan de prachtige barokorgels in Zwolle en Haarlem waar ik op heb mogen spelen alsmede de topper in de Coventry Cathedral tijdens een van onze koorreizen. Door middel van het openen van meerdere registers wordt het mogelijk om een grote klankrijkdom ten gehore te brengen. Maar hoe komt deze klankrijkdom tot stand?

Het fenomeen van boventonen doet dan zijn intrede. De grondtoon dient als basis, lees hier: de basisvakken in de geneeskunde. Doordat er in de boven octaven van de grondtoon meer resonanties ontstaan wordt de toon voller en klankrijker. De grondtoon alleen klinkt mat en kaal, de boventonen maken het tot een feestelijk vol geluid waarin het instrument ten volle wordt herkend. $U$ begrijpt: de 
boventoonmetafoor willen we graag gebruiken om het verrijkende van de revalidatiegeneeskunde voor de basisopleiding ten volle te laten klinken.

\section{Revalidatiegeneeskunde, onderwijs en UM: Docentprofessionalisering}

De uitdaging waar de revalidatiegeneeskunde nu voor staat betekent dat het onderwijs in de revalidatiegeneeskunde verder moet worden ontwikkeld. Het AIOS onderwijs binnen ons vak alsmede de docentprofessionalisering welke via het onderwijsinstituut van de UM wordt aangeboden bieden hiervoor de nodige kapstokken. Echter zonder gedreven onderwijs minded collega's lukt het niet om de meerwaarde van de revalidatiegeneeskunde tot ontwikkeling te brengen. Vandaar dat in samenwerking met het kenniscentrum Adelante, de vakgroep revalidatiegeneeskunde van de UM en de medische staf van Adelante vol wordt ingezet op verdere docentprofessionalisering. Samen met collega Jeanine Verbunt en Tom Joosten, de manager van het Kenniscentrum Adelante worden daarin geïnteresseerde AIOS en revalidatiemedewerkers via een docent professionalisering programma opgeleid tot dedicated docenten revalidatiegeneeskunde. Dit om zowel voor de FHML, UM en Adelante helder te maken dat een ontwikkeling en kennis-vermeerdering op onderwijskundig niveau noodzakelijk is. Vanuit de Adelante organisatie worden geld en tijd vrijgemaakt om dit proces op te starten. Deze inspanning levert voor nieuwe docenten resultaatverplichting op. Via het raamwerk van de onderwijskundige kennis worden de docenten met een Basiskwalificatie Onderwijs (BKO) gestimuleerd om een deel van hun werktijd te gebruiken om naast het klinisch werk onderwijs te verzorgen op de werkvloer, in onderwijsgroepen of in gastcolleges. Alleen met een professionele groep docenten kan de meerwaarde van de revalidatiegeneeskunde in de medische, biomedische en paramedische wetenschappen worden benut. Onderwijzen in iets waar je goed in bent is een feest en geeft energie. Aan de managers de taak om de dedicated docenten de ruimte te geven om het onderwijs te ontwikkelen. De onderwijscommissie van Adelante samen met de Zuyd Hogeschool is hierin een vertrekpunt en ik kijk uit naar 
verdere samenwerking met de leden van de onderwijscommissie.

Voor de faculteit FHML en Zuyd Hogeschool betekent dit het kunnen inzetten van deskundige docenten. Patiëntenzorg en onderwijs moeten een natuurlijk samenspel worden waarbij er voldoende ruimte en uitdaging is voor de docenten en waarbij planningen van de onderwijsblokken ruim van tevoren bekend zijn om planningsproblemen te voorkomen.

$\mathrm{Bij}$ docentprofessionalisering hoort naast doceren en reflectie op kennis ook beoordeling en toetsing. Een mooi voorbeeld hiervan is de interuniversitaire voortgangstoets geneeskunde waar de Universiteit Maastricht de bakermat van is. Voor diegenen die niet zo vertrouwd zijn met het concept van de voortgangstoets een korte uitleg. Het raamplan van de opleiding geneeskunde bevat een aantal eindtermen, verwoord in een lijst van klinische verschijnselen en problemen, welke de basisarts dient te beheersen.

Vanuit deze gedachte wordt de student in alle jaren van de bachelor en masterfase een toets voorgelegd van 200 vragen over de volle breedte van de geneeskunde. Voor de lezers van Medisch Contact onder ons: elke week komen er twee vragen van de toets in het tijdschrift. $U$ kunt uzelf derhalve steeds testen! Door de progressie in kennis en vaardigheden laat de gemiddelde student een kennis toename zien tijdens de toetsen over de jaren. De databank hiervoor wordt trouw beheerd door Judith van den Brink die er steeds zorg voor draagt dat de leden van de commissie aan hun verplichtingen voldoen. Omdat vakgebieden geclusterd zijn is het voor de revalidatiegeneeskunde inhoudelijk een uitdaging om relevante vragen aan de databank toe te voegen. Ons vakgebied is geclusterd met de geriatrie en in dat cluster mogen geen vragen worden gemaakt over het bewegingsapparaat. Hierbij roep ik dan ook de landelijke voortgangstoets commissie op om de indeling te herzien en revalidatiegeneeskunde te plaatsen in die context waar deze ten volle benut kan worden. Want we weten allemaal: als er een toets vraag gesteld wordt over een onderwerp dan wordt er voor gestudeerd!

Dit fenomeen van de voorgangstoets biedt binnen de specialistische opleiding revalidatiegeneeskunde eveneens uitdagende mogelijkheden. Als de bestaande landelijke kennistoets over diagnosegerichte onderwerpen aan AIOS en revalidatieartsen wordt voorgelegd worden de vragen per deeltoetsonderwerp afgenomen. $\mathrm{Er}$ is niet een alomvattende 
vakbrede toets. De toetsingscommissie van de Vereniging van Revalidatieartsen (VRA) en daarin voorop collega Jan Bakker stelt ons voor de taak om een dergelijke toets te ontwikkelen. Adaptief testen, waar Arno Muijtjens van het onderwijsinstituut UM druk mee doende is, kan een leidraad zijn om tot een evenwichtige set vragen te komen die eveneens voorbereidt op het Europees revalidatiearts examen. Dat stelt ons vak voor de uitdaging om samen een set vragen te ontwerpen die aan alle kwaliteitseisen voldoen zoals deze ook gelden in de voortgangstoets. Vanuit deze leerstoel zal samen met de toetsingscommissie een beroep worden gedaan op alle opleiders revalidatiegeneeskunde in Nederland om deze toets tot een succes te maken. Collega Henk Stam van het Erasmus MC heeft met zijn app Medigrip ${ }^{8}$ regelmatig bijgedragen aan de toets voor de revalidatiegeneeskunde en de ontwikkeling van toetsvragen. Ook AIOS en studenten geneeskunde zullen worden uitgedaagd om relevante kennisdomeinen te bestuderen en vragen aan te leveren aan de toetsingscommissie.

Het revalidatiegeneeskundig denken is in de jaren 60 met een voor mij tot voor kort onbekend leerboek vorm gegeven. Met veel dank aan collega Rein Zwierstra, voormalig prodecaan onderwijs aan de Rijksuniversiteit Groningen, die mij Het leerboek voor de revalidatie van J.H.P.Schut uit $1968^{9}$ ter hand stelde met daarin een korte persoonlijke tekst die ik hier graag citeer: "Bij het opruimen van mijn boekenkast trof ik dit leerboek aan. Dit boek past beter in jouw kast dan in die van enig ander persoon. Mooi om te zien hoe jouw vak is geëvolueerd. Veel plezier ermee". Beste Rein, heel veel dank.

De collega's destijds hadden dit boek gemaakt voor de verpleegsters van het revalidatiecentrum de Hoogstraat in Leersum ten behoeve van het volgen van een theoretische en praktische cursus voor het huisdiploma revalidatie (na een examen dat door twee gedelegeerden van de Geneeskundige Hoofdinspectie van de Volksgezondheid werd bijgewoond). Hierin werd de verpleegster en daarnaast de arbeidstherapeut onderwezen in het zo zelfstandig mogelijk maken van de patiënt. De nadruk lag op de activiteiten van het dagelijks leven. En er werd toegevoegd: de "opvoedende" taak van de revalidatieverpleegster kan van zeer veel invloed zijn op de revalidatie. 
Nadien hebben we met zijn allen erg ons best gedaan de revalidatiegeneeskunde verder vorm te geven zowel in uitwerking van de methodiek als in het verzamelen van een overzicht in verschillende leerboeken.

Deze leerboeken, aanvankelijk in de jaren 60 en 70 meer vanuit de Amerikaanse literatuur, werden aangevuld met de zg. basiscursusklappers. Dit waren gebundelde voordrachten welke aan de deelnemers van de revalidatiebasiscursussen werden uitgereikt en als naslagwerk over de laatste stand van zaken van de diagnose gebonden behandeling konden worden gebruikt. Dit heeft een groot aantal jaren goed gefunctioneerd. Bij de opleidingsvisitaties in de jaren 90 en 2000 was dit altijd een dankbaar onderwerp van beoordeling. Als je als opleidingsgroep slim was, vulde je de plank met basiscursusklappers een dag voor de inspectie door de commissie.

Nederlandstalige leerboeken waren er weinig. Daarom een groot compliment aan de vele collega's die in het belang van de ontwikkeling van de revalidatiegeneeskunde in Nederland intensief hebben gewerkt aan de totstandkoming van diverse Nederlandstalige leerboeken zoals het leerboek dwarslaesies onder redactie van Floris van Asbeck; het leerboek kinderrevalidatie onder redactie van Greet Meihuizen - de Regt en meer specialistische boeken over amputatie en prothesiologie, orthesiologie en orthopedisch schoeisel. Het in 2015 aan de voorzitter van de RGS kunnen aanbieden van het leerboek volwassenrevalidatie ${ }^{10}$ was daarbij een prachtig hoogtepunt.

Het schrijven van een leerboek is een uitdaging: Vele deskundige collega's zetten zich aan deze taak voornamelijk in de avond en weekenduren. Veel nieuwe kennis wordt toegevoegd. Daarom blijft het me verbazen dat de accreditatiecommissie van de VRA besloten heeft hiervoor geen nascholingspunten aan de auteurs toe te willen kennen, terwijl het qua bijdrage aan de ontwikkeling en kennisvermeerdering van het vak langer en uitgebreider is dan welk specialistisch A-1 artikel dan ook. Ik nodig de voorzitter van deze commissie uit met mij in discussie te gaan over de bijdrage die dit levert aan de kennisvermeerdering van de auteur! En we weten, geachte collega, je mag nu niets zeggen of tegenspreken!

Voor de methode van revalidatie mogen we de naam van Berend Bangma, destijds hoogleraar in Rotterdam, niet 
vergeten. Reeds in de jaren 70 schreef hij over de integrale benadering: Revalidatiegeneeskunde; methodologie en praktische uitvoering ${ }^{11}$ en Inleiding revalidatiegeneeskunde; patiëntgericht hulpverlenen ${ }^{12}$ welke eind jaren 80 verschenen om het revalidatiegeneeskundig proces verder te ontwikkelen. Mijn gewaardeerde collega en opleidingsgenoot Bert Kap mocht in het kader van vervangende dienstplicht als medeauteur aan de basis staan van dit laatste boek.

\section{Over de methode van revalidatie (Slot)}

Om zinloos onderzoek van de
gehandicapte te vermijden zal een
voorselectie moeten geschieden door
een deskundig arts. Op grond van het
lichamelijk onderzoek en de algemene
oriëntatie betreffende het
functioneren van de patiënt, zal hij de
revalidatie-indicatie kunnen stellen en
de loop van het revalidatie-proces in
grote lijnen kunnen voorspellen.
Een dergelijke 'eenzijdigheid' kan
bezwaren oproepen, vooral als de arts
niet is opgeleid in de revalidatie, geen
inzicht heeft in de integrale
problematiek of daarvoor geen tijd
heeft en bovendien die kennis mist,
die nodig is de mogelijkheden en
beperkingen van de andere tot
revalidatie samenwerkende
disciplines naar hun waarde te
schatten. Het streng volgen van de
methodiek van het
revalidatie-onderzoek en de oriëntatie

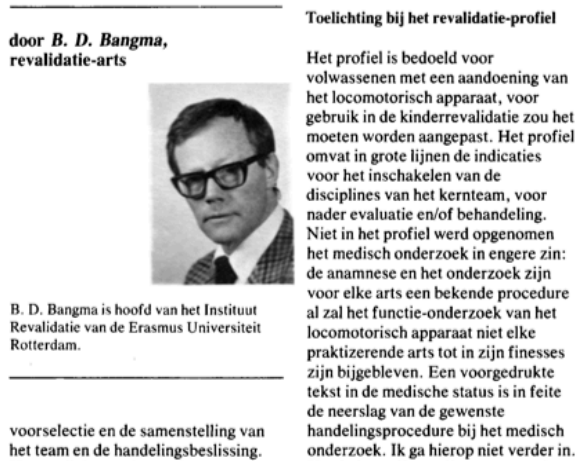

Fig 3: over de methode van revalidatie

Prof Bangma heeft daarvoor een raamwerk ${ }^{13}$ geschapen dat tegenwoordig als onderwijsmodel prima dienst doet in het inventariseren van functioneren. Wie van ons is er niet groot geworden met het SAMPC model dat het functioneren op de verschillende domeinen uiteen rafelde en kapstokken gaf voor de behandelmogelijkheden.

\section{Revalidatiegeneeskunde, onderwijs en opleiding}

Vanuit de geneeskundeopleiding met de basisvakken neem ik $U$ nu graag mee naar de boventonen van de opleiding revalidatiegeneeskunde in Nederland. Ons specialisme bestaat zoals gezegd 60 jaar en heeft in de opleiding grote ontwikkelingen laten zien. Hier moet met name de rol van het Concilium en de Scholingscommissie worden genoemd. Met name deze laatste commissie is samen met de landelijk scholingscoördinator inhoudelijk verantwoordelijk voor de inhoud van het landelijk onderwijs in de revalidatie- 
geneeskunde. Van een goed verzorgd 3 jaarlijks systeem van basiscursussen waarbij de AIOS de laatste ontwikkelingen op het gebied van CVA, dwarslaesie of amputatierevalidatie werd voorgeschoteld werd er in 2011 een nieuwe weg ingeslagen met het zogenaamde lijnleren. Daarnaast wordt nu voorzichtig een start gemaakt met het blended learning principe waarbij e-learning en boekenkennis worden gecombineerd om kennis te vermeerderen en toe te passen.

In de laatste basiscursus orthopedische schoen in Groningen, samen met de collega's Klaas Postema en Marga Tepper, hebben we de proef op de som genomen: De gehele AIOS groep werd van tevoren ad random over alle opleidingsjaren ingedeeld in twee groepen. Een groep kreeg de standaard voorbereiding met het leerboek en de cursusklapper en de tweede groep kreeg naast deze info een e-learning module in blackboard $®$ met oa een fraai vervaardigde snijzaal video over de complexe beweging van de achter- en middenvoet en de relaties met de anatomie. Hierna volgde een zelfde entree toets voor beide groepen en naderhand eenzelfde online eindtoets. De resultaten stelden ons teleur; we vonden weinig verschillen in de eindtoets kennis waarbij met name de elektronische problemen van het landelijk gebruik van de blackboard $\AA$ omgeving ons parten heeft gespeeld. Wel gaf het veel inzicht wat er allemaal moet worden gedaan om een dergelijke vorm van onderwijs en toetsing tot een succes te maken. Vandaar dat we vanuit deze leerstoel de handschoen oppakken om het elektronisch toetsen van de revalidatiegeneeskunde zowel voor medisch student, AIOS als collega specialist vorm willen geven. Het adagium life long learning is een uitdaging voor alle specialismen.

\section{Revalidatiekennisnet}

De infrastructuur die de revalidatiegeneeskunde daarvoor heeft ontwikkeld mag hier met trots worden genoemd: Revalidatie kennisnet: een online domein waar alle werkers is de specialistische revalidatiegeneeskunde aan kunnen deelnemen; therapeut, gedragswetenschapper en ondersteuners naast de specialist en de AIOS. Werkgroepen en beleidsontwikkelingen kunnen daar worden gedeeld. Door de groei van de laatste jaren wordt het wel wat minder 
overzichtelijk. Wij hebben in 2012 reeds de werkgroep Revalidatiegeneeskunde en onderwijs gestart: deze is gemaakt voor de onderwijs coördinatoren revalidatiegeneeskunde aan de verschillende medische faculteiten. We stellen ons hierbij voor onderwijs voorbeelden, werkboeken en modules met elkaar te delen en samen te zoeken naar de meest effectieve manier om de revalidatiegeneeskunde op alle niveaus te onderwijzen. Het ligt in de bedoeling om vanuit Maastricht samen met de collega's in de andere universiteiten te werken aan een landelijk onderwijsnetwerk waarbij de curricula kunnen worden gevoed met onze gezamenlijke kennis en visie op de revalidatiegeneeskunde. Dit om aan de onderwijscommissies van de medische faculteiten duidelijk te maken wat revalidatiegeneeskunde in het curriculum vermag voor de arts van morgen: We hebben $\mathrm{U}$ allen wat te bieden!

De volgende uitdaging ligt eveneens op mijn pad: in de opleiding van de AIOS is er in het kader van de individualisering de mogelijkheid om de $\mathrm{zg}$ etalagestage te doen: 3 of 6 maanden je verdiepen in een speciaal deelonderwerp. Revalidatiegeneeskundig onderwijs ontbreekt hierbij! Het ligt in mijn bedoeling om juist daarvoor een opleidingsetalage te ontwikkelen die niet alleen Maastricht aan zal doen maar wellicht ook andere collega faculteiten. Dit is nu in de verkennende fase maar zal de komende jaren verder ontwikkeld gaan worden. Immers we moeten verder ontwikkelen hoe we op de meest effectieve manier de revalidatiegeneeskunde zichtbaar kunnen maken. Want om terug te komen op de eerste vraag van de student: Wat doet de revalidatiearts? Juist het laten ervaren van de dagelijkse activiteiten in het ziekenhuis op de polikliniek, klinische afdeling of revalidatiecentrum laat meer zien dan welk college dan ook. Het keuzeblok revalidatiegeneeskunde in Maastricht, in het tweede bachelor jaar opgezet door collega Jeanine Verbunt en nu voortgezet door een van mijn steunen op deze dag Geerie Winnubst, heeft een prachtig overzicht en stimuleert studenten al vroeg in de studie geneeskunde om kennis te maken met de revalidatiegeneeskunde.

Op landelijk gebied hebben we via de medische faculteiten toegang tot veel geneeskunde studenten: hoe kunnen we hen echter bereiken? Een poging hiertoe hebben we 5 jaar 
geleden gestart met de landelijk inzetbare meeloopdag, geboren tijdens een co-assistentencongres van de KNMG en een beetje afgekeken van een der andere specialismen. Elke geneeskunde student in Nederland kan contact maken met het VRA bureau in Utrecht met de vraag om een dagje mee te lopen met een revalidatiearts in een Ziekenhuis of Centrum. In de afgelopen 4 jaren hebben ca. 150 studenten daar gebruik van gemaakt.

\section{Revalidatiegeneeskunde> investeren in kwaliteit van leven}

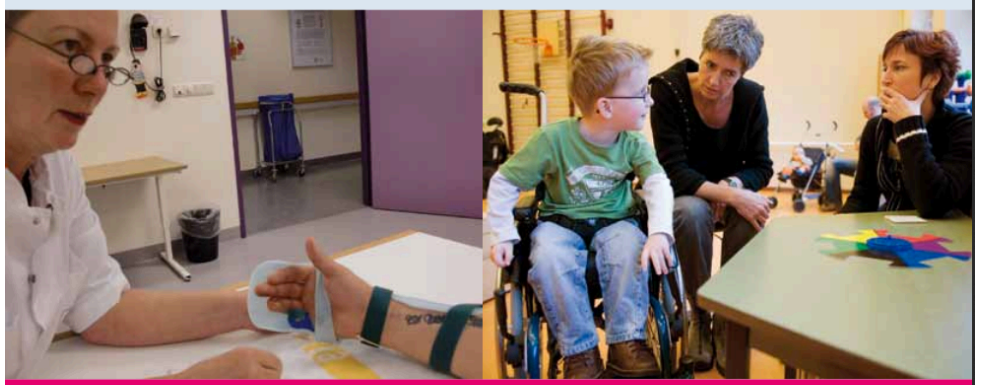

'Een mooi vak waarbij je de tijd hebt voor de mens als geheel.'

Revalidatiegeneeskunde is een breed vakgebied waarin je nauw samenwerkt met collega's uit vele disciplines. Maar wat is revalidatiegeneeskunde precies, wat doet een revalidatiearts en waar kun je een opleiding volgen?

Fig 4: studentenfolder VRA

De onderwijscoördinator revalidatiegeneeskunde is daarbij het schakelpunt om de student op zijn of haar eigen dan wel andere universiteit een laagdrempelige kans te bieden om met eigen ogen te zien wat er de hele dag gedaan wordt door de revalidatiearts. Een oproep aan alle collega's hier om je op te stellen als ambassadeur van ons vak: je weet nooit hoe het balletje gaat rollen. Ook al wordt een student huisarts, chirurg of internist: het functioneren van mensen laten ervaren geeft een mooi uitgangspunt om later in de professionele carrière aan terug te denken en te ervaren wat je tijdens een meeloop dag hebt gezien: wellicht moeten we nog nadenken over een landelijke goodiebag met revalidatiedingen om verder te komen. 
Hier in Limburg hebben we alvast een voorzet gemaakt met de goniometer (hoekmeter gewrichtsbewegingen) waarbij de Adelante organisatie samen met de UM in de zak van de keuzeco-asisstent verdwijnt, samen met een QR code naar de website van de VRA. Wellicht een voorbeeld voor anderen om de dokter van morgen dit soort handige instrumenten ter hand te stellen!

Tijdens onze VRA congressen nu in mooi Engels de DCRM geheten zijn we reeds 5 jaar bezig om steeds een workshop te geven aan medisch studenten over wat de revalidatiegeneeskunde nu inhoudt. $\mathrm{Er}$ wordt gebruik gemaakt van eigen ervaringen, wetenschap en de studentenposterwalk. Het bereiken van de geneeskunde student blijft daarbij continu een punt van aandacht; Flyers helpen maar ten dele, een social media VRA account is er, wellicht moeten we dat koppelen aan de websites van de geneeskundeverenigingen. Dit kost geld maar naar mijn idee goed besteed voor de toekomst. We hebben een uniek vak waar we trots op zijn en dat we graag willen uitdragen.

Over de Engelse taal valt nog wel het een en ander te zeggen: de wensen van de universiteiten om alle kennisoverdracht in het Engels te doen stelt het onderwijs ook hier in Maastricht open voor grotere groepen van buiten. Toch maak ik hier graag een kanttekening voor de geneeskunde opleiding: Juist in de Masterfase geneeskunde, tijdens de coschappen, komt zowel hier in Maastricht als overal de lokale patiënt de spreekkamer in. Door mijn verschillende werkplekken heb ik kennis mogen maken met het Fries, Gronings en Utrechts en nu, $U$ voelt hem aankomen, als "hollander" in Maastricht. De coassistent moet in staat zijn om in Jip en Janneke taal de patiënt iets uit te leggen.. Tijdens de onderwijsgroepen wordt het nu al een vreemde mengelmoes van Nederlands, Engels en verbasteringen van de Latijnse termen van de anatomie. Ik pleit ervoor om in de Masterfase, voor een goede beroepsuitoefening als arts in Nederland, het Nederlands in het onderwijs centraal te blijven stellen. Er zijn uitdagingen genoeg voor de docenten en de tweetalige curricula geven mogelijkheden, maar leveren in het onderwijs van alle dag, zeker als dat patiënt gebonden is, wel problemen op. Of moeten we de zorgverzekeraar vragen standaard een cursus Engels te vergoeden aan de patiënt om met de arts te kunnen blijven communiceren? 


\section{De Entrusted Professional Activity}

De Entrusted Professional Activity (EPA) wordt ook voor de revalidatiegeneeskunde ontwikkeld. Dit zijn vanuit het oogpunt van het specialisme die kenmerkende activiteiten die de revalidatiearts in zijn algemene praktijk in ieder geval moet beheersen. Door een werkgroep van het Concilium worden deze EPA's nu ontwikkeld. We willen allemaal een goed opgeleide revalidatiearts voor de toekomst en hebben daarvoor de kenmerkende praktijk nodig. De AIOS wordt daartoe opgeleid en dit wijkt af van het bestaande leerplan BETER waar we een aantal jaren geleden hard aan hebben gewerkt. Voorbeelden van de EPA voor de revalidatiegeneeskunde zijn: grotere kennis en vaardigheden die alle aspecten van de CANMEDS betreffen. Voorbeelden hiervan zijn: de basis medische zorg in het revalidatiecentrum, het technische spreekuur voor orthesen en schoenen en bv het opstellen van decubitusbeleid en het uitvoeren van de behandeling. Voor de ontwikkeling van de AIOS hebben we in de conceptversie van 8 november 2016 eveneens de EPA: Onderwijs en supervisie verzorgen Basis en Differentiatie geplaatst voor scholing in deze vaardigheden. Deze laatste kan een mooie opmaat zijn voor de eerder genoemde etalagestage onderwijs welke afgesloten zou kunnen gaan worden met de EPA: Onderwijs en supervisie verzorgen differentiatie.

Olle ten Cate heeft vanuit de Universiteit Utrecht een aanzet gegeven tot de ontwikkeling deze EPA's ${ }^{14}$. Ook voor de revalidatiearts van de toekomst dienen deze EPA's de leidraad te worden voor de nieuwe opleiding waarbij we de nu gebruikte diagnose gebonden themakaarten gaan vervangen. De eerder genoemde landelijke toetsing zal hierop moeten gaan aansluiten. Ook voor de life-long learning van onze revalidatiecollega's gaan de zaken derhalve veranderen.

Binnen de verschillende diagnose gebonden werkgroepen van de VRA wordt toenemend gediscussieerd over de plaats en voorwaarden waaronder de hooggespecialiseerde revalidatiebehandeling dient te worden uitgevoerd. Kenniscentra voor pijn en andere meer diagnose gebonden aandoeningen zijn zich aan het ontwikkelen; Een voorbeeld hiervan is de Werkgroep Amputatie en Prothesiologie (WAP) 
van de VRA. Binnen het opstellen van het behandelkader worden meerdere deskundigheidsnivaus aangegeven waarbij het revalidatieteam over meer kennis, opleiding en vaardigheden moet beschikken. Zoals $U$ weet draag ik deze doelgroep een warm hart toe. Het begon tijdens de doctoraalfase geneeskunde in Utrecht in 1984. De oudere amputatie patiënt leidde onder mijn promotor Prof Willem Eisma uit Groningen tot de promotie in de medische wetenschappen. Deze oudere amputatie patiënt wil graag dicht bij huis worden behandeld. Het liefst om de hoek zodat de vaak op leeftijd zijnde familie en vrienden hem ook kunnen blijven bezoeken. Wat nu te doen met de EPA die we ontwikkelen voor de AIOS: als het de hoog specialistische revalidatiezorg betreft waarbij de dubbelzijdige Knieexarticulatie of Transfemorale amputatie wordt behandeld op niveau 2 of 3 ver weg van eigen huis en haard. En wat betekent dit voor de opleiding van de AIOS en de exposure van de geneeskunde student welke toch ook deze patiëntengroep wil zien? Voorwaar een uitdaging.

\section{Het Diabetisch Voetenteam}

Binnen deze doelgroep wil ik $U$ graag laten zien welke prachtige mogelijkheden ons vak heeft om interdisciplinair te acteren en te onderwijzen in het ziekenhuis. Een voorbeeld dat ik graag vanuit Maastricht wil laten horen is het multidisciplinaire diabetes voeten team waarbij we als groep samen met Nicolaas Schaper, internist en godfather van de diabetische voet en met Joris Hermus, orthopedisch chirurg, Jan Willem Dahmen, vaatchirurg en niet te vergeten Ron Sleegers als medische duizendpoot: verpleegkundig specialist, gipsverbandmeester, en podotherapeut ineen, door het ziekenhuis trekken waarbij de revalidatiearts steeds het functioneren van de patiënt met de voetproblemen centraal stelt. Zoals Hans Emmen, orthopedisch schoenmaker, het met mij eens is: De wonden ontstaan echt niet altijd door de schoenen. Vanuit ieders deskundigheid wordt er op hoog niveau zorg verleend waar een scala aan AIOS van verschillende specialismen en co-assistenten en semiartsen aan deelnemen. Een waar Eldorado voor kennisoverdracht, samenwerking en opleiding. Ik hoop met deze collega's de gezamenlijke visie op de groep verder vorm te geven en te onderwijzen met de paramedici en technici. In dit verband moet zeker de International Society 
of Prosthetics and Orthotics (ISPO) als verbindend element worden genoemd. Een interdisciplinaire samenwerking van medici, therapeuten en technici op het gebied van amputatie en prothesiologie waar de overdracht van kennis op alle niveaus op de voorgrond staat. En voor wie het wellicht niet weet vanaf vandaag is de internist Schaper toegetreden tot de ISPO, waar we trots op zijn. Nicolaas welkom binnen de ISPO! Met elkaar bouwen we verder aan de toekomst.

\section{Het interdisciplinair opleiden}

Binnen de interdisciplinaire samenwerking in het ziekenhuis maken we veelvuldig contact met AIOS van andere specialismen. Op de werkvloer geven we de gedachten rond het functioneel denken door aan de AIOS van bv interne geneeskunde, chirurgie, orthopedie en neurologie. De eigen AIOS revalidatiegeneeskunde worden daarbij conform het individueel opleiden regelmatig van feedback voorzien welke wordt opgenomen in hun portfolio. Het mede beoordelen van AIOS van andere specialismen door de revalidatiegeneeskunde staat evenwel in de kinderschoenen. Niet dat we de intentie hebben om de chirurgische vaardigheden te beoordelen maar op de domeinen samenwerken en gezondheidsbevordering is het goed mogelijk om de AIOS van feedback te voorzien. De verschillende portfolio's maken het lastiger om dit individueel vast te leggen. Echter in navolging van de Fieldnote van de co-assistenten: d.i een korte notitie over een of twee aspecten van de geobserveerde activiteit, geven op veel momenten de mogelijkheden om een korte notitie in een evaluatie moment te gebruiken. Dit kan dan door de AIOS zelf aan zijn opleidingsportfolio worden toegevoegd. Ook omgekeerd kan de revalidatie AIOS veel leren van de feedback van de neuroloog of chirurg: Volgens mijn overtuiging kunnen we daarmee nog meer aandacht geven aan het toepassen van interdisciplinaire activiteiten tijdens de opleiding van de verschillende specialismen. Een kans die we als opleiders revalidatiegeneeskunde zeker moeten pakken. 


\section{Revalidatiegeneeskunde en boventonen: de synthese}

We komen nu tot een afronding van deze oratie: voor de revalidatiegeneeskunde liggen er kansen binnen de basisopleiding geneeskunde en de vervolgopleiding revalidatiegeneeskunde samen met de Adelante organisatie. Ons specialisme is een breed vak met vele vertakkingen binnen het ziekenhuis. Voor de geneeskundeopleiding hebben we de faculteit FHML veel te bieden en willen die taak graag met deskundige collega's volop uitdragen. Natuurlijk blijven er wensen over: zoals genoemd de uitbreiding van de voortgangstoets, het interdisciplinair opleiden van geneeskundestudenten, paramedici en de medische vervolgopleidingen.

Een woord van dank aan de faculteit FHML in de persoon van de decaan prof Scherpbier: $U$ hebt net zoals ik Groningse vertakkingen in het verleden. $U$ stelt veel vertrouwen in mij en de revalidatiegeneeskunde door het instellen van deze leerstoel. Het college van toezicht welke inhoudelijk met mij optrekt ben ik erkentelijk voor de mogelijkheden.

De raad van bestuur van het MUMC+ dank ik voor het blijven stimuleren van het opleiden.

Mijn collega's Rob Smeets en Jeanine Verbunt: we houden elkaar in evenwicht met aandachtsgebieden waarmee we de revalidatiegeneeskunde op de kaart kunnen zetten. Fijn om dit samen met jullie te doen! Alle revalidatie collega's binnen het MUMC+ en de Adelante organisatie: we gaan het samen doen: dank daarvoor. Fijn dat ik op jullie kan rekenen.

Tot slot wil ik iedereen die een bijdrage heeft geleverd aan mijn vorming tot arts, revalidatiearts, opleider en docent van harte bedanken. Het is een feest om hier te staan. Ik hoop met $U$ de titel van deze oratie: Over basisvakken en boventonen waar te gaan maken. 
$\mathrm{U}$ bent hier nu te gast op historische grond zoals zoveel plaatsen in Maastricht. Om de geschiedenis van dit oorspronkelijke klooster recht te doen heb ik het volgende verzoek aan de Universiteit Maastricht. In verschillende aula's van de medische faculteiten zoals o.a. in Utrecht en Amsterdam staan er in een zaal als deze volwaardige pijporgels om prachtige orgelmuziek te laten klinken. Daarom daag ik het college van bestuur van deze universiteit en de faculteit FHML uit om het mogelijk te maken bij mijn afscheidscollege $U$ te kunnen trakteren op de orgel boventonen van de revalidatiegeneeskunde !

Ik heb gezegd. 


\section{Literatuur}

1. Meij, W.K.N. van der.

Een specialisme in beweging. Een eeuw revalidatie, vijf decennia VRA

2005 uitgegeven door van der Meij ISBN 9789080950214

2. Fysische diagnostiek, boek \& online, 2e herziene editie Uitvoering en betekenis van het lichamelijk onderzoek.

Redactie drs. T.O.H. de Jongh (hoofdredacteur), dr. H.E.M. Daelmans, drs. M.J. Dekker, dr. W.L.M. Kramer, prof. dr. R. Remmen, drs. Ch.P.M. Verhoeff, drs. G.M. Verwijnen 2015 ISBN 9789036808927

3. http://www.mocatest.org/wp-content/uploads/2015/testsinstructions/MoCA-Instructions-Dutch72.pdf

4. Arch Phys Med Rehabil. 1998 Jan;79(1):10-3.

Mandatory clerkship in physical medicine and rehabilitation: effect on medical students' knowledge of physiatry. Kirshblum SC, DeLisa JA, Campagnolo DI.

5. Disabil Rehabil. 2010;32(23):1948-54.

Teaching medical students rehabilitation medicine.

Gibson J1, Lin X, Clarke K, Fish H, Phillips M.

6. ICF Nederlandse vertaling van de International Classification of Functioning, Disability and Health 2007; ISBN 9789031350988

7. http://www.vilans.nl/Kennis-en-informatie-publicaties-infographichervormingen-langdurige-zorg.html

8. http://medigrip.org/

9. Leerboek voor de Revalidatie 1968 Ed J.H.P.Schut. Uitgeversmaatschappij de Tijdstroom, Lochem.

10. Revalidatie voor volwassenen

J.H.B. Geertzen, J.S. Rietman en G.G. VanderStraeten

2014 van Gorcum ISBN: 9789023250791

11. Revalidatie-geneeskunde; methodologie en praktische uitvoering Bangma, B.D. Van Gorcum, Assen [etc.], 1989

12. Inleiding revalidatie-geneeskunde; patiëntgericht hulpverlenen

Bangma, B.D.; Kap, A. Van Gorcum, Assen [etc.], 1988

13. B.D.Bangma

Over de methode van revalidatie (slot)

(1978) MEDISCH CONTACT 33439

14. Entrustability of professional activities and competency-based training. ten Cate O. Med Educ. 2005;39(12):1176-1177. 
